\title{
Urban Poverty: Community Empowerment through National Program for Community Empowerment towards in Batam City
}

\author{
Diah Ayu Pratiwi
}

\begin{abstract}
This study examines community empowerment in overcoming poverty through PNPM (Program Nasional Pemberdayaan Masyarakat/ National Program for Community Empowerment) - Urban in Batam City. The purpose of this study was to identify the stages of participation of the poor in PNPM activities and analyze the stages of achievement of the poor after PNPM ended, this research was carried out because there were no studies that specifically discussed the achievements of the poor after the end of PNPM, especially whether the poor who participated in PNPM activities had come out of poverty. PNPM - Urban emphasizes community participation where all activities are left to the community itself, starting from socialization, poverty identification, organization, planning, implementation, to the utilization and maintenance of the results of activities. This study uses qualitative research. Data obtained by observation and in-depth interviews with 12 informants using purposive sampling technique. The results of this study indicate that community participation is at the stage of delegation of power, but the urban poor in Batam City still depend on government assistance and have not escaped poverty. The concept of community empowerment has not been optimal in the PNPM.
\end{abstract}

Keywords: Community Empowerment, Urban Poverty Alleviation, PNPM-Urban, Batam City.

\section{INTRODUCTION}

Community empowerment is an effort to create/enhance the capacity of the community, both individually and in groups, in solving various problems related to efforts to improve the quality of life, independence and welfare (Sulistyani 2017).

In Indonesia, one of the poverty reduction programs based on community empowerment is the National Program for Community Empowerment (PNPM). PNPM is oriented towards community participation, in its implementation handed over to the community through government assistance and monitoring. This allows the community to be directly involved in various levels of development programs ranging from planning to program evaluation.

PNPM is implemented throughout the Province of Indonesia. This program is considered successful by the government in reducing poverty in Indonesia. Through this program, the number of poor Indonesians decreased from

Revised Manuscript Received on September 22, 2019.

Diah Ayu Pratiwi, Riau Kepulauan University, Batam City, Indonesia. diah_mahdan@yahoo.co.id
16.58 percent in 2007 to 10.12 percent in 2014 (Indonesia 2019). This has reached the RPJM (Mid Term Development Planning) target (2010 - 2014), where the poverty target is 8-10 percent in 2014. The decline in the number of poor people does not only occur in rural areas, but also in urban areas which have decreased from 12.52 percent in 2007 changed to 8.16 percent in 2014 (Indonesia 2019).

Batam is one of the cities in the Riau Islands Province, participating in implementing PNPM Urban. The implementation of PNPM Urban in Batam is not able to reduce poverty in Batam. In 2010 - 2013 the poverty rate in Batam declined from 7.26\% - 5.20\%. However, in 2014 2018 it has increased from 5.3\% - 5.11\% (City 2019). Some cities in Indonesia have succeeded in reducing poverty through the PNPM Urban, but not for Batam.

Based on the statistical data above, researchers are interested in conducting research on the implementation of PNPM Urban in Batam. The researcher wanted to identify the stages of community participation in PNPM activities and analyze the stages of achievement of the poor after the end of PNPM activities, especially whether the poor who participated in PNPM activities had left the poverty line.

\section{Literature RevieW}

\section{A. Community Empowerment}

Etymological empowerment comes from the word power. Empowerment is defined as giving or increasing power to weak or disadvantaged people. Empowerment is the expansion of assets and the ability of poor people to participate in, negotiate with, influence, control, and hold institutions accountable for influencing their lives (Narayan 2002). Empowerment refers to efforts to reallocate power through changing social structures, where people, organizations, and communities can be directed to be able to master their lives.

Empowerment is a process and purpose. As a process, empowerment is a series of activities to strengthen the power or empowerment of weak groups in society, including individuals who experience problems of poverty. And as a goal, empowerment refers to the situation or outcome that a social change wants to achieve, that is, the poor who are empowered, have the power or have the knowledge and ability to fulfill their needs, both physical, economic and social, such as having 
confidence, being able convey aspirations, have livelihoods, participate in social activities, and be independent in carrying out their life's tasks. The definition of empowerment as a goal is often used as an indicator of the success of empowerment as a process (Suharto 2005).

Empowerment is intended to improve people's welfare. Community empowerment implies developing, self-supporting right, and strengthening the bargaining position of the lower classes of society towards pressure forces in all sectors and sectors of life (Pranaka 1996). In empowering the community there are three possible approaches, namely: community mobilization, community participation, and community development The three approaches, in particular, will be directed at two objectives: namely, empowering people from setbacks and poverty, also known as community empowerment and strengthening community position in a government structure known as community political empowerment (Sumodiningrat 1999). Departing from various definitions of community empowerment that people who have been empowered should know the capabilities and resources they have to escape poverty.

\section{Community Participation in Empowerment}

The word participation is interpreted etymologically from Latin participate or participation. The term participation itself comes from participare verbs which means to participate (Karianga 2011). Thus participation contains an active understanding, namely the existence of activities or activities. The concept of participation has long been the subject of research studies.

Participation is define as mental and emotional involvement of a person in a group situation which encourages him to contribute to group goals and share responsibility in them (Davis 1962). Community participation in development generally starts from the stage of making decisions, implementing decisions, enjoying the results and evaluating activities (Uphoff 1977).

Community participation is simulated as the distribution of power between community members and local government. Furthermore, the distribution of power can be identified in the gradation of power based on the degree of community participation put forward by Arnstein (Arstein 1971).

Table 2.1 Degree of Participation (Arstein, 1971)

\begin{tabular}{|c|c|c|c|}
\hline No. & $\begin{array}{c}\text { Degree of } \\
\text { Participatio } \\
\text { n }\end{array}$ & $\begin{array}{c}\text { The Essence of } \\
\text { Participation }\end{array}$ & $\begin{array}{c}\text { Degree of } \\
\text { Distribution } \\
\text { Power }\end{array}$ \\
\hline 1 & Manipulation & $\begin{array}{l}\text { No communication } \\
\text { especially dialogue }\end{array}$ & \\
\hline 2 & Therapy & $\begin{array}{l}\text { There is } \\
\text { communication but it } \\
\text { is still limited, } \\
\text { initiatives come from } \\
\text { the government and } \\
\text { only focus on one } \\
\text { direction/ } \\
\text { socialization }\end{array}$ & $\begin{array}{c}\text { Degree of } \\
\text { Non } \\
\text { Participation }\end{array}$ \\
\hline
\end{tabular}

Communication

already exists but it is

still one-way and

$3 \quad$ Informing

there is no

opportunity for the community to provide feedback

The community is

4 Consultation heard, but the advice

is not always used

Community advice is

$5 \quad$ Placation accepted but not always implemented Enables community to negotiate and

6 Partnership

engage in trade-offs with traditional power holders

Communities are given power (some or

Degree of Citizen power

$\begin{array}{cc}7 & \begin{array}{c}\text { Delegated } \\ \text { Power }\end{array} \\ 8 & \text { Citizen } \\ \text { Control }\end{array}$
all programs)

Full managerial power

Referring to the degree of participation according to Arnstein (1971) that the degree of community participation can be identified by examining where the participation originates from the government, the community or together between the government and the community.

\section{Methodology}

This study applies a qualitative research, which is an approach that emphasizes the withdrawal of conclusions based on interpretation of a phenomenon or fact. The scope of this study is very limited, because it runs in a small area (micro), namely the construction of social facts in one of Kelurahan of Batam City located in Tiban Lama, sub district of Sekupang. Implementation of the data collection is implemented by using a moderate participant observation. Withdrawal of informants based on purposive sampling technique with some respondents. It is a technique of sampling data sources with special consideration (Patton 2002), where informants have the knowledge and experience of PNPM Urban. Data analysis was carried out by triangulation originating from observations, interviews and documents.

\section{RESUlts AND FindingS}

\section{A. Community Participation in PNPM Urban}

Based on the results of observations and interviews at the research location that the level of community participation in the PNPM Urban, namely:

The level of community participation in initiative indicators is at the level of delegated power. At this degree, participation that occurs is citizen power participation. The community has been given the authority to determine the program to be implemented, but in some criteria, the role of

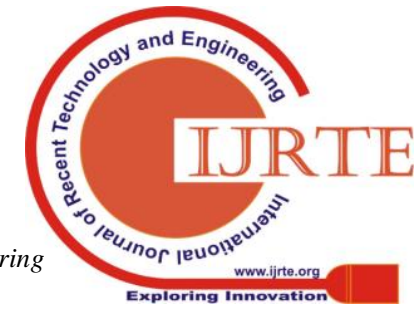


the government still exists. Planning the initial idea of program activities has come from the community.

The level of community participation in financing indicators is at the level of informing. At this degree, participation that occurs is tokenism participation. The characteristics of low income people make it difficult for the community to get involved in financing PNPM Urban. Self-help issued by the community is dominated by labor. However, in carrying out physical activities, it is not uncommon for people to contribute their self-help in the form of consumption.

The level of community participation in decision-making indicators is at the level of delegated power. At this level, participation that occurs is active participation. There is a division of authority between the community and the government in this case the neighborhood unity/community groups apparatus related to decision making.

The level of community participation in the indicator of power mobilization capability is at the citizen power level. At this level, there has been active participation, in which the community determines all in terms of mobilization of personnel. The large number of productive ages, sufficiently available laborers in the construction workforce, and the continuing spirit of mutual cooperation, is one of the reasons why it is easy to mobilize local workers in the implementation of PNPM Urban in Tiban Lama. The role of neighborhood unity/community group officials and community leaders is quite dominant in inviting the public to be involved in activities.

The level of community participation in indicators of the ability to solve problems is at the level of partnership. At this level, active participation has taken place. Communities and governments work together even with other parties to solve existing problems.

\section{B. Achievement Phase of the Community After the End of PNPM Urban}

As a program that emphasizes aspects of empowerment and involving community participation, Urban PNPM is implemented in the Tiban Lama through the tridaya program. The PNPM Urban program consists of three programs, namely PNPM Urban oriented to community empowerment that emphasizes community participation. The PNPM Urban Program consists of areas of empowerment namely environmental (infrastructure), economic, and social empowerment.

Activities in the tridaya program, including environmental empowerment programs, are programs for building environmental and health facilities and infrastructure. Economic empowerment program, which is a revolving loan. Meanwhile, social empowerment programs are more about training, counseling and compensation Based on the findings that the implementation of the tridaya program is to prioritize environmental rather than social and economic empowerment. This was confirmed by a statement from BKM Nusa Indah Coordinator:

The PNPM program is prioritized on environmental empowerment ... road repairs, repair of bridge and drainage repairs ... because the funds disbursed by the government are mostly directed towards the construction and repair of infrastructure ... while the funds for revolving loans and social empowerment are not so much disbursed.

The government prioritizes environmental empowerment so that regions in Indonesia, especially urban areas, are free from slums which become the Government's Strategic Plan. However, the implementation of this program is not optimal at the research location. Because after the program ended, the community did not maintain the infrastructure that had been built.

Similarly, economic empowerment has many problems. Providing capital assistance benefits the sustainability of their business. Typically, the purpose of a revolving loan program is to help communities increase productive commercial activity capital to improve their virtues. Majority of the informant claim that this function did not function optimally because short-lived capital assistance during the loan repayment period, capital assistance was used for personal needs, and the presence of people who embezzled revolving loan funds.

At first, I joined PNPM to get a revolving loan fund ... yes ... to increase business capital. After I got a loan ... the money was used more to buy daily necessities. Because the loans obtained are few and cannot increase business capital (Informant 12, PNPM beneficiary, 2018)

I have not returned the revolving loan in this second phase ... I have not benefited from my business ... the money I got from the revolving loan in the second facility ... I use it for daily expenses (Informant 9, PNPM beneficiary, 2018).

Based on the above statement that revolving loan funds cannot be maximized by the community to increase their business capital. The economic empowerment program is not yet in increasing their economic income, because the revolving loan funds that they cannot help in developing their business.

Referring to the concept of community empowerment as an effort to develop and strengthen the potential that the community already has (Setiana 2005). The community empowerment approach implemented PNPM Urban in Tiban Lama has not been able to optimally strengthen the potential of the urban poor. Because there are a number of programs, the government is still intervening regarding the priority of the programs implemented. The poor have not succeeded in decision making. In addition, there are more programs implemented by the community for short-term rather than long-term results.

\section{ConClusion}

The results of the study showed that the level of participation of the community in Tiban Lama is largely at the stage of delegated power, although for some criteria the role of the government still exists. In the PNPM Urban program, the community has been given power from planning, implementation to maintenance of the results of activities. In terms of maintenance activities have 
not run optimally because the infrastructure program has begun to break down after PNPM ends.

The stage of achievement of the poor after PNPM Urban ends that the poor still depend on government assistance. The PNPM Urban program has not been able to increase their economic income. The implementation of community empowerment through PNPM Urban prioritizes the environment (infrastructure) compared to the economic sector. In terms of the use of the traditional program budget, the infrastructure program that uses the funds is greater compared to economic and social programs. Poverty reduction programs based on community empowerment should be focused more on economic and social empowerment. The poor are given training or courses that can develop potential within themselves and then are given business capital with clear rules. With an economic and social empowerment program that can increase their economic income and escape poverty.

\section{REFERENCE}

[1] Arstein, S. (1971). "A Ladder of Citizen Participation." Journal of The American Planning Association 35(4).

[2] City, S. o. B. (2019). Poverty in Batam Municipality 2011-2018. Batam, Statistic of Batam City.

[3] Davis, K. (1962). Human Relation at Work. New York, McGraw Hill Book Company Inc.

[4] Indonesia, S. (2019). Number of Poor Population, Percentage of Poor Population and Poverty Line, 1970-2017. Jakarta, Statistic Indonesia.

[5] Karianga, H. (2011). Partisipasi Masyrakat dalam Pengelolaan Keuangan Daerah (Perspektif Hukum dan Demokrasi). Jakarta, PT. Alumni.

[6] Narayan, D. (2002). Empowerment and Poverty Reduction: A Source Book. D. Narayan. Washington, World Bank.

[7] Patton, M. Q. (2002). Qualitative Research and Evaluation Methods. Thousand Oaks, Sage Publication.

[8] Pranaka, O. S. P. a. A. M. W. (1996). Pemberdayaan: Konsep, Kebijakan dan Implementasi. Jakarta, Center for Strategic and International Studies.

[9] Setiana, L. (2005). Teknik Penyuluhan dan Pemberdayaan Masyarakat. Bogor, Ghalia Indonesia.

[10] Suharto, E. (2005). Membangun Masyarakat Memberdayakan Rakyat. Bandung, Refika Aditama.

[11] Sulistyani, A. T. (2017). Kemitraan dan Model-model Pemberdayaan. Yogyakarta, Gava Media.

[12] Sumodiningrat, G. (1999). Pemberdayaan Masyarakat \& JPS. Jakarta, Gramedia.

[13] Uphoff, J. C. a. N. T. (1977). Rural Development Participation: Concept and Measures for Project Design-Implementation and Evaluation. New York, Cornell University Press.

\section{AUTHOR PROFILE}

I am Diah Ayu Pratiwi, I am working in Riau Kepulauan University, Batam City, Indonesia. Area of interest is social sciences. 